\title{
INCLUSÃO SOCIAL NA USP: MÉRITO E DIVERSIDADE
}

O Brasil precisa de universidades consideradas "internacionais", que disputem o título de melhores do mundo e participem das discussões mais importantes nos campos da ciência, tecnologia e humanidades. A USP aspira à classe de universidade internacional e, para tanto, precisa concentrar esforços em diversos âmbitos, um dos quais indubitavelmente diz respeito à manutenção criteriosa da qualidade de seu corpo discente. Para permanecer em sua trajetória de busca da excelência internacional, a USP deve continuar agregando em seus quadros os melhores talentos egressos do Ensino Médio. Deve, também, criar estratégias para identificar candidatos cujo potencial acadêmico latente não pode ser totalmente evidenciado pelos resultados de processos de seleção. Abrem-se, então, novas perspectivas para o recrutamento de estudantes capacitados, mas cujo baixo capital cultural traz a eles desvantagens nos exames de admissão para a graduação.

A diversidade da população universitária também é fator a ser considerado na caracterização de uma universidade de renome mundial, pois os alunos se beneficiam de uma educação mantida em um ambiente plural, originado por diferenças culturais, socioeconômicas, raciais, entre outras. Nesse espaço, há mais oportunidades para a expressão e o aperfeiçoamento de talentos e habilidades, o que resulta em melhoria da qualidade da experiência educacional e no preparo para uma cultura cada vez mais complexa. Como consequência, o processo de proposição e avaliação de ideias novas pode ser aprofundado e conduzido de maneira respeitosa e civilizada, com vistas à excelência individual e coletiva.

É fato conhecido que alunos de estratos socioeconômicos mais favorecidos têm amplo conhecimento sobre a USP e seu vestibular, razão pela qual o interesse por uma universidade pública de qualidade faz parte do cotidiano familiar. O mesmo não ocorre com alunos de escolas públicas, para os quais referências sobre a USP são escassas e o fenômeno da autoexclusão exerce importante papel. Na maioria dos casos, os pais não reconhecem a educação como ferramenta para a mobilidade social. Assim, para minimizar a importância da condição socioeconômica no ingresso na universidade com base em políticas de inclusão e permanência transparentes e de longo prazo, em 2006 a USP criou o INCLUSP, Programa de Inclusão Social da USP. Na ocasião, definiu-se o perfil dos candidatos que deveriam receber o apoio da universidade no âmbito de sua nova política de inclusão social, assim como a natureza do apoio oferecido. Com o intuito de sinalizar que a manutenção do mérito é o parâmetro que norteia sua missão institucional, mas demonstrando a preocupação com a diversidade na graduação, a importância do aumento da procura pelos seus cursos e o papel da instituição na contribuição para a melhoria da qualidade do Ensino Médio público, decidiu-se que o critério a orientar a política de inclusão seria social. Dessa forma, foi definido que o foco do programa seriam os alunos da rede pública e o apoio no ingresso seria feito por meio de bônus na nota do vestibular.

Em 2008, foi criado o PASUSP, Programa de Avaliação Seriada da USP, uma iniciativa inovadora que busca a aproximação com a escola pública e que atribui bônus maior a alunos do Ensino Médio público, com potencial acadêmico destacado e que cursaram integralmente o Ensino Fundamental em escolas públicas. Em função do desempenho na prova da $1^{\text {a }}$ fase da FUVEST, esses estudantes podem ter acréscimo diferenciado na nota do vestibular. A partir de 2011, o PASUSP foi também estendido a alunos de $2^{\circ}$ ano, com o objetivo de antecipar o contato desses estudantes com a USP e seu vestibular. Além disso, o teto do bônus foi aumentado, podendo atingir o valor de $15 \%$ para alunos com bom desempenho na $1^{\mathrm{a}}$ fase da FUVEST. Finalmente, cumpre ressaltar que, desde 2011, alunos inscritos no PASUSP estão automaticamente isentos do pagamento da taxa de inscrição do vestibular, com o objetivo de minimizar barreiras para a participação desses estudantes no vestibular. Esse conjunto de recentes ações tem sido responsável pelo significativo aumento no número de alunos de escolas públicas inscritos no vestibular nos últimos dois anos.

A operacionalização do PASUSP requer divulgação entre alunos e professores da escola pública e os efeitos benéficos dessa etapa são fundamentais para apresentar a USP como perspectiva atraente, desejável e possível aos futuros egressos do Ensino Médio. O estreitamento de relações da universidade com as escolas da rede pública tem sido realizado de maneira bastante efetiva pelo programa Embaixadores da USP, em que docentes e alunos de graduação e pós-graduação visitam centenas de escolas públicas do Estado de São Paulo, criando novas perspectivas na busca de referências para a melhoria do ensino e da autoestima. Assim, promove-se o contato da comunidade uspiana com os professores e os alunos da rede pública, visando à troca de experiências acadêmicas. Ao se inscreverem para participar do programa, os estudantes visitam o site da FUVEST, recebem informações sobre a universidade e seu programa de permanência estudantil e passam a enxergar a USP como um possível projeto de vida. Portanto, o PASUSP é um canal eficiente de comunicação da USP com as escolas públicas, criado para resgatar o espaço perdido nas últimas gerações. A intenção do programa é cultivar no estudante da escola pública paulista a ideia de que a USP, uma universidade de excelência, pode e deve fazer parte de seu horizonte de possibilidades. No momento em que esta opção se descortina para os alunos da rede pública, fica claro que ela tem um preço: estudo e dedicação. É desta maneira que o PASUSP pode colaborar para a melhoria do ensino, visto que os alunos vão se esforçar e exigir mais dos professores, criando um círculo virtuoso de aperfeiçoamento para que a escola pública possa ter novamente o padrão de qualidade ostentado no passado e claramente deteriorado nas últimas décadas.

Não é a capacidade intelectual que está distribuída de maneira desigual em nossa sociedade, mas, principalmente, as oportunidades. Há pessoas extraordinárias que emergem de classes sociais menos abastadas e que, se motivadas, conseguem desenvolver novos talentos e usá-los para construir projetos dinâmicos e criativos, vislumbrando um mundo que pode ser diferente. Uma sociedade prudente deve estar atenta a esse fato, maximizando opções, fazendo um investimento para um futuro estável e demonstrando a todos que sonhos são realizáveis. Muitas dessas pessoas têm em comum o fato de serem conscientes de que elas podem definir seu próprio destino, a despeito das limitações socioeconômicas. A USP quer atrair essas pessoas por acreditar que o apoio oferecido no processo de seleção e, após o ingresso, nos programas de permanência estudantil, será convertido em desempenho acadêmico amplamente satisfatório, conforme já atestam dados de anos anteriores. Os reflexos positivos do programa de inclusão social da USP poderão ser evidenciados num futuro próximo, caso se verifique a melhoria da qualidade dos cursos de graduação, a maior motivação dos alunos da rede pública e a criação de um ambiente universitário mais propício para o desenvolvimento da excelência acadêmica e científica no Estado de São Paulo.

A USP é uma instituição educativa formada por professores, alunos e funcionários e tem como missão a produção, preservação e disseminação de conhecimento altamente especializado. Atualmente, tem havido contínuas e justificadas pressões para maior inclusão social, levando-se em consideração inclusive aspectos étnicos, de tal forma a exigir da instituição uma nova função social. Ocorre que ao se tornar um espaço de assistência e conforto, tentando ser justa para que os mais necessitados possam dela fazer parte, a USP corre o risco de a proteção, importante para não elitizar a universidade, converter-se num fim em si mesmo, garantindo a todos os cidadãos (mesmo os que não são aptos) benefícios intermináveis. A dedicação ao serviço social, embora compreensível, tem como consequência a perda de foco e o atraso do desenvolvimento científico e acadêmico. Saber lidar com esta dicotomia (inclusão x mérito) vai exigir da universidade, no futuro próximo, capacidade de discernimento, visão política e coragem. A USP será tão mais importante para o país quanto mais clara for sua missão específica na promoção do avanço da ciência, artes e humanidades, na difusão de abordagens educacionais inovadoras e no estabelecimento de uma interface transparente com a população. Nesses termos, a sociedade terá convicção da importância da USP como um de seus maiores patrimônios. 